\title{
LEGAL QUESTIONS IN THE OPERATION OF THE LICENSING SYSTEMS
}

\author{
VIRGIL W. COOPRIDER*
}

Prior to national Prohibition, the responsibility for liquor control was left, with few exceptions, to local officials. As a result, policies and procedures varied with each locality and were subject to frequent change. From this situation there developed a chaotic condition which greatly accentuated the need for a uniform national policy and was thereby one of the principal factors in bringing about Prohibition. ${ }^{1}$ Since Repeal, the tendency has been to follow a middle course and centralize control in the state and thus provide a basis for working out uniform state policies. It was upon this theory that state legislators undertook the task of drafting new liquor control legislation. Since the pre-Prohibition statutes were of little help, most of this legislation has been experimental. The 45 states not having prohibitory provisions have set up varied types of control in an effort to determine the type best adapted to the particular state. The types of control adopted by these states may be divided into two general categories. ${ }^{2}$ Seventeen have instituted systems of state operation of liquor stores generally referred to as monopoly systems. The remaining 28 states have restricted private trade by establishing liquor licensing systems. Most of the states, finding their earlier efforts not completely satisfactory, have continued to amend, add to, or delete portions of existing statutes. This experimentation, and the fact that enforcement of liquor control legislation is one of the most difficult tasks of government, has resulted in much litigation raising many interesting legal questions concerning the control systems. This article deals only with questions arising out of the licensing systems as brought out by a study of the reported decisions of courts since Repeal.

Since the licensing system of control generally operates through an administrative agency, many of the questions or problems that arise are those applicable to administrative tribunals generally. These questions may be divided into three broad categories. First, questions concerning delegation of power. Second, questions arising

* A.B., 1938, State Teachers College, Pittsburg, Kansas. Third-year student, Duke University School of Law. Member, Editorial Board, Duke Bar Association Journal.

${ }^{1}$ See Byse, Alcoholic Beverage Control before Repeal, stspra 544, at 549.

${ }^{2}$ Any classification of states on the basis of a single type of control system is superficial. In the so-called monopoly states, the monopoly generally extends to sale of package liquors only. A separate license system is set up in some of these states for sale of liquor for consumption on the premises, or for sale of light wines and beer. Even in the "dry" states, license systems are used for regulation of the sale of beer. 
out of the exercise of the powers delegated. Third, methods by which one aggrieved by action of the control authority may obtain administrative or judicial relief.

\section{Questions Concerning Delegation of Power}

One of the most common attacks made upon the liquor licensing systems is that upon the validity of the transference of power from the legislature to the licensing authority. Most of the states having a licensing system have placed the dominant control of the liquor traffic under existing state fiscal agencies or under specially appointed state liquor control officers or boards. However, in only four states is the control of these agencies exclusive. The other states have granted to local authorities, either county, municipal, or a combination of both, a power of participation in the control. ${ }^{3}$ In general, the power vested in these agencies by the legislatures may be divided into two parts: (I) the power to issue, deny or revoke licenses and, (2) the power to make such rules and regulations as may be deemed necessary for the efficient administration of the state control statute. It is an attack upon the foundation of this control structure that is made by litigants, generally licensees who have been adversely affected by a decision or regulation, in an effort to have the control statute declared unconstitutional as an illegal delegation of power.

Although all of the states have constitutions which either expressly require separation of powers of the various branches of government or which are construed as requiring such separation, ${ }^{4}$ it is generally recognized that a legislature may delegate administrative functions if a standard is prescribed as a guide for the action of the administrative agency. 5 Under this general rule, several types of questions arise as to the licensing systems.

What powers may be delegated? By and large, the delegation of authority has been very broad, the powers of control agencies over persons and property extraordinarily sweeping. For example, control authorities are given discretionary power to issue, deny, or revoke licenses, power to determine suitability of persons and premises for licenses, hold hearings, fix the number of licenses, forbid brewers, wholesalers, or manufacturers to have any interest in the retail licensee's property, regulate hours, location, size of containers, labeling, prices, advertising and employees. ${ }^{0}$ Furthermore, it should be noted that these powers are not limited to control over intoxicating liquor. Several cases have raised the question whether the delegated powers include the power to regulate non-intoxicating liquors. ${ }^{7}$ Without exception, the courts have held that, since the legislature has the power to regulate liquors which are non-intoxicating in order to make its control of intoxicants effective, this power

${ }^{3}$ Culver and Thomas, State Liquor Control administration A Statutory Analysis (1940) 2.

- Goodnow, The Principles of Administrattve Law of the United States (1905) 31.

${ }^{5}$ Berger v. Quinn, r49 Misc. 545, 268 N. Y. Supp. 514 (1933); Coady v. Leonard, I32 Ohio St. 329, 7 N. E. (2d) 649 (1937).

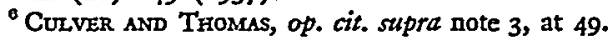

"Johnson v. Board of County Commissioners, I47 Kan. 21 I, 75 P. (2d) 849 (x938); Berger v. Quinn, supra note 5; Fylken v. City of Minot, 66 N. D. 25I, 264 N. W. 728 (z936); Riggins v. Dist. Court of Salt Lake County, 89 Utah I83, 5I P. (2d) 645 (1935); Hinebaugh v. James, I19 W. Va. I62, I92 S. E. 177 (1937). 
may be delegated along with the power to control intoxicants. The courts have been very liberal with the legislatures in their control efforts and have permitted them to place these broad powers in the control agencies generally stating the reason to be the harmful nature of the subject matter dealt with. ${ }^{8}$

The power of the control agency which has been most frequently attacked is the discretion which it may exercise. The vesting in the control body of adequate discretionary powers in issuing, denying and revoking licenses, however, is one of the most important factors of successful liquor control. ${ }^{\ominus}$ The many factors connected with licensing which cannot be adequately provided for by definite rules or by provisions of the statute make the exercise of discretionary powers imperative. The cases present several illustrations of the desirability of this power. In a New York case, ${ }^{10}$ the State Liquor Authority revoked a restaurant liquor license on the ground that the licensee had ceased to operate a bona fide restaurant. At the time the premises were inspected, the only food found was a half box of uncooked spaghetti. The court upheld the right of the authority to exercise discretion. In a similar case, ${ }^{11}$ the Connecticut Commission refused to grant a restaurant liquor permit on the ground that, although the place was well equipped to do restaurant business, it was merely a sham and not a bona fide restaurant. The Supreme Court of Errors of Connecticut upheld the action of the Commission as not arbitrary or an abuse of discretion.

Most states except clubs from some of the restrictions of the control statutes such as a prohibition of the sale of alcoholic beverages in places concealed from public view. Because of these exceptions or privileges, the attempt is frequently made to be classed as a club. ${ }^{12}$ The control agency must have free discretion to discriminate between false and bona fide applications for club licenses.

Exercise of discretion is also desirable where a close relative of an ineligible person applies for a liquor license. Thus, in a Connecticut case where the plaintiff's husband had been denied a license after which the plaintiff applied for a license in her own name, the court upheld the Commission's refusal to grant the permit as a valid exercise of its discretion. ${ }^{13}$

The liquor control laws in general show that the legislatures have recognized the desirability of administrative discretion. Most of the statutes now contain provisions granting such discretion to the control authority either expressly or by implication from the language used. Where there has been an express provision for exercise of discretion, the courts usually interpret the statute to mean reasonable

${ }^{8}$ Premier-Pabst Sales Co. v. State Board of Equalization, I3 F. Supp. 90 (I935).

${ }^{-}$Harrison and Lane, After Repeal (I936) $8 \mathrm{I}$.

${ }^{10}$ Scalise v. State Liquor Authority, I60 Misc. 390, 289 N. Y. Supp. 939 (I936).

11 Melarose v. Liquor Control Commission, I23 Conn. 318, r94 Atl. 725 (1937).

${ }^{12}$ Meserole v. Liquor Control Commission, r25 Conn. 463, 3 Atl. (2d) 664 (1939); Liquor Control Commission v. Fraternal Order of Eagles, 286 Mich. 32, 28I N. W. 427 (I938); Commonwealth v. West Philadelphia Fidelio Mannerchor, II5 Pa. Super. 24I, X75 Atl. 434 (x934); Appeal of Young Men's Republican Club, ז25 Pa. Super. 486, 190 Atl. 527 (1937); Portuguese-American Independent Social Club v. Costello, 6 Atl. (2d) 7I7 (R. I. 1939).

${ }^{13}$ Wilks v. Liquor Control Commission, 122 Conn. 443, 190 Atl. 262 (r937). 
discretion. ${ }^{14}$ Under this interpretation, if a court finds that the authority acted arbitrarily or in abuse of its discretion, that action will be held invalid. ${ }^{15}$ However, the courts tend to sustain the action of the control authority under its discretionary power. In upholding action of the authority under this power, the courts generally state that they are not authorized to hold the licensing body's action arbitrary or capricious where such action is based on evidence from which reasonable men might honestly differ. ${ }^{16}$

Although most courts require that the discretion be reasonable, some have held that where a statute expressly confers a power to exercise discretion the licensing authority may even act arbitrarily or capriciously. ${ }^{17}$ For example, the court in a Georgia case ${ }^{18}$ in upholding the control authority's refusal to grant a license said, "Any person engaging in the business of selling malt beverages can lawfully do so only upon the basis of a mere privilege which the designated authorities are authorized to grant or refuse, or even to revoke after grant, in the exercise of an arbitrary discretion. The privilege is based upon a mere permit and may be refused for any reason or arbitrarily."

The right of the authority to exercise discretion may be implied in several ways. It has been held that the licensing authority has discretion where the statute provides that licenses "may be denied for cause"19 or where the authority should "consider the requirements of the community"20 before granting a license. If the statute definitely specifies the requirements which an applicant must comply with, the control authority may exercise a certain amount of discretion in determining if the requirements have been met. ${ }^{21}$ This is especially true where the qualifications contain the words "suitability of person" or "suitability of place," or "good moral repute." For example, the Iowa control statute ${ }^{23}$ provided, among other requirements, that the licensing authority should satisfy itself of the good moral character of the applicant. In a case involving this provision, ${ }^{24}$ the court refused to grant a writ of mandamus to compel the authority to issue a license on the ground that the authority had the right to exercise discretion in determining the moral character of the applicant. Although a statute specifically sets out certain grounds upon which the authority may deny or revoke a license, it has been held that these grounds are not exclusive and the authority has discretion to deny or revoke for other reasons. ${ }^{25}$

\footnotetext{
${ }^{14}$ Gwiazda v. Borgin, I21 Conn. 705, I85 Atl. 4 I6 (1936); Silberglied v. Mulrooney, 150 Misc. 250, 270 N. Y. Supp. 290 (I934); Wright v. State, I76 Tenn. 628, ro6 S. W. (2d) 867 (r937).

${ }^{15}$ Loglisci v. Liquor Control Commission, 123 Conn. 31, I92 Atl. 260 (1937).

${ }^{16}$ Van de Vegt v. Board of Commissioners, 98 Colo. 16I, 55 P. (2d) 703 (1936).

${ }^{17}$ Phillips v. Head, I88 Ga. 51r, 4 S. E. (2d) 240 (1939); Scott v. Township Board, 268 Mich. I70, 255 N. W. 752 (I934).

${ }_{10}$ Yates v. Mulrooney, 245 App. Div. r46, 28I N. Y. Supp. 216 (r935).

${ }^{20}$ Van de Vegt v. Board' of Commissioners, supra note 16.

${ }^{21}$ In te Mark, II5 Pa. Super. 256, r76 Atl. 254 (r934).

${ }^{22}$ Loglisci v. Liquor Control Commission, supra note 15; Fylken v. City of Minot, supra note 7.

${ }^{23}$ Iowa CODE (1935) c. 93-F2, \$192I-fro3.

24 Madsen v. Town of Oakland, 219 Iowa 216, 257 N. W. 549 (r934).

${ }^{25}$ Blum v. Ford, I94 Ark. 393, ro7 S. W. (2d) 340 (x937); In re Mark, supra note 21; cf. Klipsch v. Ind. Alcoholic Beverage Commission, 215 Ind. 6I6, 2 I N. E. (2d) 70I (1939).
} 
Although most of the states confer upon the state agency a power to make rules and regulations, only four license states specifically provide in the statute that such rules and regulations shall have the force and effect of law. ${ }^{26}$ Thus it would seem that, in these states, violation of such rule or regulation would be treated as a criminal offense. Where such provision is not included in the statute, the effect is doubtful. It is also doubtful whether the legislature can confer upon the state agency the power to say that a violation of certain of its rules shall be a crime. In the cases involving this point that have arisen in this field, it has been held that this could not be done. ${ }^{27}$ The New York act provided that "violation by any person of any rule of the State Board shall be a misdemeanor if such rule so provides."28 The Board instituted a rule prohibiting sale of liquors during certain hours on Sunday and provided that a violation should be a misdemeanor. The defendant violated the rule and was convicted. The appellate court reversed the conviction, ${ }^{29}$ holding the provision of the act was invalid as an attempt to delegate to the unrestricted volition of an administrative board so essentially a legislative function as the definition of a substantive criminal offense. Thus, it seems that if the legislature declares that violations of the rules of the Board shall be a misdemeanor, the provision is valid. But the legislature cannot allow the Board to make the declaration according to this case.

Scope of the powers granted. Although the courts tend to refrain from placing restrictions upon the legislatures in their delegation of power in this field, they are more strict in their supervision of the administrative agency in its exercise of such powers. The administrative body must confine its activity strictly to the scope of the powers delegated. Thus in the Connecticut case of Loglisci v. Liquor Control Commission, ${ }^{30}$ the Commission revoked a license on the ground that the licensee was an unsuitable person because he employed his infant son on the premises. The act did not forbid the employment of minors but did give the Commission a discretionary power to revoke licenses and to enforce the provisions of the act and "to make all needful rules and regulations for that purpose." The act also provided that "every regulation made by the Commission shall have the same force and effect as law, unless and until set aside by some court of competent jurisdiction or revoked by the Commission." The court held that since the employment of minors was not forbidden by the act or by a regulation of the commission, the commission exceeded its power when it revoked the license on this ground. Said the court, "The power conferred to make regulations for carrying a statute into effect must be exercised within the powers delegated, i.e. must be confined to details for regulating the mode of proceeding to carry into effect the law as it was enacted, and it cannot be extended to amending or adding to the requirements of the statute itself." Some of the state

\footnotetext{
${ }^{20}$ Culver and ThOMas, op. cit. supra note 3 , at 42.

${ }^{27}$ People v. Grant, 242 App. Div. 310, 275 N. Y. Supp. 74 (1934); People v. Ryan, 267 N. Y. 133, 195 N. E. 822 (1935).

${ }^{20}$ People v. Ryan, supra note 27.

${ }_{28}$ N. Y. Laws 1933, c. $180, \$ 97$ subd. 4.

${ }^{30}$ Supra, note I5.
} 
acts definitely provide that rules and regulations promulgated by the board shall not be inconsistent with the act. ${ }^{31}$

It may be of interest here to note other instances in which the action of the state authority has been successfully contested on the ground of excess of authority. A ruling of the New York A. B. C. Board requiring all persons receiving a license to sell liquor to publish a notice once a week for two successive weeks in a daily paper was held to be unauthorized as the statute provided that publication could be in either daily or weekly papers. ${ }^{32}$ A regulation of the Connecticut Liquor Control Commission providing that liquor could be sold by druggists only under a package store permit, although the act provided that the Commission should issue, among other types of permits, druggist as well as package store permits, was held void as beyond the power of the Commission. ${ }^{33}$ A New Hampshire court held that the state control commission could require a licensee to furnish a key to the enforcement officers of the commission but it could not require an additional key to be furnished to the local chief of police. ${ }^{34}$

In Maine, the State Liquor Commission made a regulation requiring out-of-state manufacturers and wholesalers to obtain a certificate of approval costing $\$ 200$ before they could do business in the state. The court vigorously denounced this action as an usurpation of a prerogative which belonged to the legislature. ${ }^{35}$ In this instance, the act not only did not provide for such regulation, but the legislature had recently voted against placing a provision in the act requiring: such a certificate. It is interesting to note that the legislature of New Hampshire earlier had placed such a provision in its act which was upheld by a federal court as not an undue interference with interstate commerce. ${ }^{38}$

How definite must the standard prescribed by the legislature be? To what extent must the legislature determine policy by the statute or to what extent may that be left to the control agencies to determine through rules, regulations and decisions? The courts have generally held that the standard set out by the legislature to guide the control authorities has been sufficient. ${ }^{37}$ Some of the courts have expressed the opinion that, since the state may completely prohibit the sale of liquor, the standard may be a very general one. Thus it has been said that the standard may be in its nature a general one if it is capable of reasonable application under the circumstances. $^{38}$ The court in an Ohio case ${ }^{39}$ even intimated that a standard of any kind might be dispensed with in legislation of this type. In this case, the state control board restricted the advertising of intoxicants almost to the point of prohibiting it.

${ }^{31}$ City of De Ridder v. Mangano, 186 La. I29, I7x So. 826 (1936); Bodkin v. State, 132 Ncb. 535, 272 N. W. 547 (1937).

${ }^{32}$ Sesselberg v. Schoeneck, 15I Misc. 267, 272 N. Y. Supp. 588 (1933).

${ }^{33}$ Murphy v. Bergin, 118 Conn. 249, 171 Atl. 433 (1934).

${ }^{34}$ Manchester Press Club v. State Liquor Commission, 89 N. H. 442, 200 Atl. 407 (1938).

35 Anheuser-Busch v. Walton, 135 Me. 57, Igo Atl. 297 (I937).

${ }^{38}$ Dugan v. Bridges, I6 F. Supp. 694 (1936).

${ }^{37}$ Johnson v. Board of County Commissioners, supra note 7; Gaine v. Burnett, r22 N. J. L. 39,4 Atl. (2d) 37 (1939); Bird and Jex Co. v. Funk, 96 Utah 450, 85 P. (2d) 83 I (1939).

38 Berger v. Quinn, supra note 5.

${ }^{30}$ Coady v. Leonard, stipra note 5. 
The state act provided only ". . . the Board of Liquor Control shall have power to adopt rules and orders necessary to carry out the provisions of the act including . . . uniform rules and regulations governing all advertising with reference to the sale of beer and intoxicating liquors throughout the state and advertising upon and in premises licensed for its sale." 40 In holding that this was a valid delegation of power, the court said, "But the rule [requiring a standard] relaxes somewhat as to the necessity for such limitations and restrictions, where wide power is imperative in law enforcement, and many authorities have held that standards or criteria for guidance are not necessary in cases in which the discretion to be exercised by the administrative officers relates to police regulations, protection of public morals, health, etc. . . . The standards or criteria set up by this statute are all sufficient when due weight is given to the object sought to be accomplished with reference to a traffic which the state may not only regulate, but entirely prohibit in the exercise of the police power."

Other cases have raised the problem of the power of the legislature to confer upon the control agency discretion to determine what applicants shall be granted a license without setting out specific qualifications in the statute to guide the agency. This delegation of power is generally upheld by the courts. ${ }^{41}$ A typical statement of the reasoning is found in the Indiana case of Fry $v$. Rosen. ${ }^{42}$ "The true distinction is between the delegation of power to make the law, which necessarily involves discretion as to what it shall be, and conferring an authority or discretion as to its execution, to be exercised under and in pursuance of the law." In many instances where local authorities must approve a license issued by the state authority before the license becomes operative, the matter is left to the discretion of such local authority without any standard whatever to govern its action. ${ }^{43}$ Concerning such a provision, the court in the case of Scott v. Township Board of Arcada Township ${ }^{44}$ said, "The discretion given the authority means the power to act officially according to what appears to it to be just and proper under the circumstances."

Participation of local authorities. As was pointed out earlier, the most important delegation of power is that made to the state control authority. The power of the legislature to set up ministerial agencies for this purpose is well established and has been questioned in very few cases. ${ }^{45}$ Beyond the delegation of power to state agencies, 23 license states provide for local participation by delegating power of liquor control to local authorities. ${ }^{46}$ One other state vests the entire control in local authorities. ${ }^{47}$ The power of the legislature to make this delegation seems to have been well settled by cases arising before Prohibition. ${ }^{48}$ Since Repeal, the power has been

${ }^{10}$ Ohio Gen. Code (Page 1938) $\$ 6064-3$.

1 Mckown v. City of Atlanta, I84 Ga. 221, rgo S. E. 57 I' (1937).

43207 Ind. 409 , $x 89$ N. E. 375 (1934).

${ }^{4}$ Hodges v. Kennedy, 184 Ga. 400, 191 S. E. 377 (1937); Thielen v. Kostelecky, 69 N. D. 410,287 N. W. 513 (1939).

268 Mich. I70, 255 N. W. 753 (1934).

${ }^{46}$ Fry v. Rosen, supra note 42; Berger v. Quinn, supra note 5.

"Culver and Thomas, op. cit. supra note 3 , at 3 and Table $\mathrm{I}$.

${ }^{4}$ Ibid.

${ }^{48}$ Town of Houma v. Houma Lighting Co., I2I La. 21, 46 So. 42 (1908); State v. Hearn, 59 Ore. 227, II7 Pac. 4I2 (IgrI). 
questioned in very few cases ${ }^{49}$ and successfully in none. The amount and type of power vested in these local authorities vary greatly. ${ }^{50}$ In some states, local authorities are given only power to approve or disapprove licenses granted by the state and to recommend revocation. In other states, local authorities are vested with substantially the same powers exercised by the state agencies. They may issue and revoke licenses and make rules and regulations. In at least one state, such rules and regulations must not be less stringent than those of the state agency. ${ }^{51}$

By their regulations in some states, local authorities may partially prohibit the sale of alcoholic beverages. For example, they may fix the hours of sale and forbid sale on Sunday and holidays; $;^{52}$ they may limit the number of licenses issued; ${ }^{53}$ and they may prohibit sale in certain locations by zoning ordinances and by rules denying a right to a license for any premises within a fixed distance from a church, school, hospital, etc. ${ }^{54}$ Although partial prohibition may be achieved through this regulatory power, the power does not include the right to completely prohibit unless expressly granted. ${ }^{55}$ Likewise, the grant of power to use discretion in issuing or refusing licenses usually is held not to confer a power to prohibit by refusal to issue any license. ${ }^{56}$ However, some courts have construed the discretionary power as a substitute for local option and allowed local authorities to achieve complete prohibition in this manner. ${ }^{57}$ In the Scott case, ${ }^{58}$ the court said that the purpose of allowing the local authority to exercise discretion "was to permit each local municipality to determine whether beer and wine should be sold. To avoid expense incident to submitting the question to the voters, its determination was left to the governing local authority."

The power to completely prohibit any sale in the city or county is frequently expressly granted. This prohibition may be accomplished in one of two ways. First, the governing authorities, by ordinance or otherwise, may forbid the sale. The second method of local prohibition, and the more common, is local option. Although it would seem that the question of whether local option is an illegal delegation of power to the voters had been settled long ago, the question was raised in a recent

\footnotetext{
${ }^{59}$ Boyer v. Del. Liquor Commission, I73 Atl. 522 (Del. r934); Tate v. Seymour, I81 Ga. 801, 184 S. E. 598 (I936).

${ }^{50}$ Culver and Thomas, op. cit. stipra note 3 , at 54 and Table XII.

${ }^{51}$ Jefferson County ex rel. Grauman v. Jefferson County Fiscal Court, 274 Ky. 91, I1 8 S. W. (2d) 181 (1938).

E2 State ex rel. Floyd v. Noel, I24 Fla. 852, I69 So. 549 (1936); Mallock v. City of Mt. Morris, 287 Mich. 666, 286 N. W. 600 (1939); People v. Ryan, supra note 27; Townley v. Bruckman, 168 Misc. 422, 5 N. Y. S. (2d) 899 (1938).

${ }^{53}$ Jefferson County ex rel. Grauman v. Jefferson County Fiscal Court, supra note 5I; Fenson v. Statc Liquor Authority, 244 App. Div. 847, 278 N. Y. Supp. 433 (I935).

${ }^{54}$ Silberglied v. Mulrooney, sttpra note I4; Jacob Oberson Inc. v. Seyopp Corp., 251 App. Div. 170, 295 N. Y. Supp. 346 (1937); Walker v. Pierce, x92 Ark. 797, 94 S. W. (2d) 693 (1936).

${ }^{5 t}$ Boyer v. Del. Liquor Commission, supra note 49 ; Walker v. Mayor, 187 Ga. 237, 200 S. E. 268 (I938).

${ }_{E 6}^{6}$ Thomas v. Ragsdale, $x 88$ Ga. 238, 3 S. E. (2d) 567 (1939).

${ }^{57}$ Johnson v. Board of County Commissioners, supra note 7; Scott v. Township Board of Arcado Township, supra note 44 . 
Tennessee case. ${ }^{59}$ The court dismissed the contention briefly with the statement, "the law is complete in itself and leaves to voters only the question of its local operative effect."

A somewhat similar problem arose in Kentucky under the state act providing that no license should be granted for any place within 200 feet of a church, school or hospital without written permission of such institution. Having been denied a license on this ground, an applicant instituted an action asking that the provision be declared unconstitutional as an unlawful delegation of power to those institutions. The Kentucky Court of Appeals answered the contention by saying that the provision was similar to a local option provision and was valid. ${ }^{60}$

Other questions concerning delegation of power. The delegation of powers other than the legislative has been questioned in litigation arising in this field. An interesting contention was made by a plaintiff in a Massachusetts case. ${ }^{61}$ The Commission had made a regulation specifying methods of sterilizing glasses used by licensees in business. The plaintiff contended that this was an usurpation of the power of the state board of health. In upholding the action of the Commission, the court held that there was nothing in the act setting up the board of health which was repugnant to the exclusive jurisdiction of the Commission over all matters relating to alcoholic beverages.

In an attempt to have a provision of the Indiana Liquor Control Act declared unconstitutional, one plaintiff contended that an administrative function had been delegated to the judiciary. ${ }^{62}$ The state statute gave a right of appeal from the Alcoholic Beverage Commission but gave the court only the power to pass upon the reasonableness of any orders made by the board and to decide whether or not they are lawful. The court upheld the provision as not conferring an administrative function upon the judiciary.

The reverse of this last argument has been asserted in a few cases, the contention being that there has been an illegal delegation of judicial power to an administrative agency. The basis of such contention is generally the inclusion in the statutes of provisions conferring a discretionary power on the control agencies in issuing and revoking licenses and a power to hold hearings and ascertain facts. In a Pennsylvania case $^{\mathrm{B3}}$ in which the control board revoked a license and, under its discretionary power to do so, ordered forfeiture of bond, the surety contended that the exercise of the discretionary power to forfeit or not to forfeit a penalty bond is a judicial function which cannot constitutionally be delegated to an administrative agency. The court refused to consider this contention and dismissed the case on a technical point of procedure.

This contention of illegal delegation of judicial power is usually answered by the

\footnotetext{
${ }^{50}$ Clark v. State $e x$ rel. Bobo, 172 Tenn. 429, x13 S. W. (2d) 374 (1938).

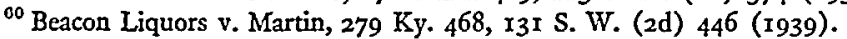

${ }^{a 1}$ Universal Machine Co. v. A. B. C. Commission, I6 N. E. (2d) 53 (Mass. 1938).

"2 Klipsch v. Ind. Alcoholic Beverage Commission, 215 Ind. 616, 21 N. E. (2d) 701 (r939).

${ }^{a 3}$ Commonwealth v. Penelope Club, I36 Pa. Super. 505, 7 Atl. (2d) 558 (r939).
} 
courts in one of two ways. Some courts say that the powers exercised are administrative and not judicial and, therefore, not illegal. ${ }^{64}$ Other courts uphold the provisions by holding that the functions are not judicial within the prohibition of delegation of judicial power, but are only quasi-judicial. ${ }^{65}$ This line of reasoning is well illustrated in the case of Keller v. Kentucky A.B.C. Board. ${ }^{66}$ Here the Board revoked a license to sell beer on the ground that the licensee was selling whisky without a license to do so, although the licensee had not been convicted of such sale. It was the exercise of this discretionary power of revocation that the licensee contested as an unconstitutional delegation of judicial power. In reviewing the case, the Kentucky Court of Appeals upheld the action of the Board. The Court states that administrative boards and commissions have become an essential part of governmental structure and in many instances it is necessary to grant power to these bodies which in some respects combine judicial, legislative and executive action and that these agencies must necessarily be given discretion in performing their duties of administering the law and in the matter of promulgating detail rules and regulations. "The existence of the ground upon which the license was revoked as a fact was a proper issue to be determined by the board as a fact finding body. There is no Constitutional objection to the exercise of such discretionary power as ascertaining facts and administering the law. True it is a quasi-judicial act, but it is not the exercise of judicial power within the meaning of that term as embodied in the constitution forbidding one department from usurping the functions of another."

The court in the Keller case concludes its opinion with this significant statement: "The act ... provides that the courts, on review, may determine whether or not there was any substantial evidence to support the order of the board." In this statement another possible reason for the liberality with which the courts tend to treat liquor control legislation may be seen. In most states, ample provision is made for review of action of the administrative control agencies, thus enabling the courts to check action of the agency when desirable. It may be that as long as such review is provided for, the courts will not hesitate to permit legislatures to delegate broad powers over the control of liquor to administrative agencies.

\section{Questions Arising Out of Exercise of the Powers Delegated}

Many questions or problems arise out of the exercise of the powers which are vested in the various control agencies. These problems involve such questions as the rights of parties applying for licenses, grounds upon which licenses may be denied or revoked, proper procedure for revocation of licenses, and others.

The basis of many of these questions has been the provision of federal and state constitutions that no person may be "deprived of life, liberty or property without due process of law." The cases arising in the pre-Prohibition era seem to have quite definitely decided that liquor control statutes did not violate any of the provisions

${ }^{04}$ State ex rel Zugravu v. O'Brien, I30 Ohio St. 23, x96 N. E. 664 (1935).

${ }^{65}$ Townley v. Bruckman, supra note $52 . \quad{ }^{68} 279 \mathrm{Ky} .272, \mathrm{r} 30 \mathrm{~S}$. W. (2d) 821 (1939). 
of the Fourteenth Amendment of the Federal Constitution. According to these cases, the right to engage in the sale of intoxicating liquors is not a privilege or immunity of citizens of the United States which the states are forbidden to abridge, ${ }^{, 7}$ nor do the control statutes deprive a person of liberty or property without due process of law. ${ }^{68}$ Finally, they hold that no one is deprived of the equal protection of the laws by these statutes unless such statutes provide classifications that are arbitrary. ${ }^{69}$ However, since the cases arising after Repeal have continued to raise the questions, it may be well to consider a few of them and note the attitude of the courts today.

Denial of application for license. In general, the courts since Repeal have taken the same attitude toward these questions as the pre-Prohibition courts. The contention that the applicant for a license is denied liberty or property without due process of law by the licensing authority's refusal to grant a license is generally answered by the courts by the use of the term "police power." to protect the health, morals and welfare of the public, the state may completely prohibit the sale of alcoholic beverages and, therefore, no one has an absolute right to sell them. Since the control statutes permit sale only under a license, the license is a mere privilege and an applicant is denied nothing to which he has an absolute right. This reasoning is well illustrated in the Fry case ${ }^{71}$ in which the applicant was denied a license and contends that the action violated the Fourteenth Amendment of the Federal Constitution. There the court upheld the action of the licensing authority stating, "It is entirely for the General Assembly to say whether any permits shall be granted and upon what terms; and since neither appellee nor anyone else has any legally recognized interest in the securing of a permit, apart from the terms and conditions of the Alcoholic Beverage Act, it follows that none of the provisions of either the Indiana or the United States Constitutions designed to protect personal or property interests can be violated by the director's refusal to grant a permit to any particular person. Charter rights, license rights, contract rights are all subject to the inherent power of a government to protect the health, morals or welfare of the public. . . . The Supreme Court of the United States has frequently held that the Federal Constitution is not involved in the restrictive or prohibitive legislation of the states when exercised under its police power."

Closely related to the contention that the applicant is deprived of liberty or property without due process of law are the arguments that refusal to grant a license denies the applicant of the "equal protection of the laws" or that the state has abridged a "privilege and immunity" of a citizen. The equal protection argument arises when the state statute makes a distinction between classes of business or per-

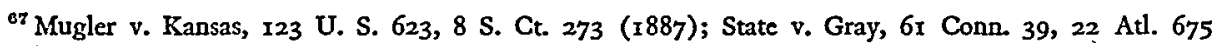
(189r).

${ }^{\circ 8}$ Mugler v. Kansas, supra note 67; Brown and Bennett v. Powers, 146 Iowa 729, r25 N. W. 833 (rgro).

${ }^{00}$ White v. Brocelin, I44 Mich. 332, 107 N. W. 1055 (1906); Bloomfield v. State, 86. Ohio St. 253, 99 N. E. 309 (1912).

70 Tate v. Seymour, supra note 49; Berger v. Quinn, supra note 5; Texas Liquor Control Board v. Marine Exchange Social Club, 127 S. W. 967 (Tex. 1939).

${ }^{72}$ Supra note 42.
} 
sons. ${ }^{72}$ A good illustration is the Kentucky statute which provides that no license shall be granted for any place within 200 feet of a church, school or hospital, but excepts from this prohibition drug stores, hotels and private clubs. ${ }^{73}$ The provision was upheld in a case ${ }^{74}$ in which the court used this typical reasoning, "It is within the province of the legislature to make such classification as it deems best under its police power, and we are not concerned with the wisdom of the Act of the legislature, but only with its constitutionality. If that classification is not so arbitrary as to be unreasonable, and is put upon a rational basis which is calculated to accomplish the protection of the public safety, health, or morals, the courts cannot interfere with it." As to the argument that denial of a license violates the Fourteenth Amendment in that it abridges a privilege or immunity of a citizen of the United States, the courts seem to be unanimous in holding that the right to sell intoxicating liquors is not one of the privileges and immunities of citizens of the United States. ${ }^{75}$

Revocation of licenses. Constitutional questions similar to those arising out of a denial of application for a license are also raised by licensees whose licenses have been revoked. The courts generally answer the due process argument with reasoning similar to that used in the cases involving a denial of a license. However, the additional argument or reason is used in revocation cases that a license is not property in any legal or constitutional sense and, therefore, a revocation made in pursuance of the statute does not deprive the licensee of property without due process of law regardless of how serious a loss may result. ${ }^{76}$ In this connection, it is interesting to note that a liquor license has been held not to be property in the sense that it may be pledged, inherited or sold. ${ }^{77}$ The reason for this is to insure that the licensees will hold their licenses free from any device which would subject them to the control of other persons.

The argument has also been made that revocation of a license impairs the obligation of contract and, therefore, violates the Federal Constitution. The courts answer this contention with the statement that a license is not a contract within the meaning of the constitutional provision forbidding the impairment of obligations of contract. ${ }^{78}$

The procedure necessary to revoke a license varies from state to state. The sentiment of the courts concerning revocation of licenses in general has been that if a license confers merely a privilege upon its holder, the privilege may be withdrawn without notice and without opportunity to be heard or even without any reason being

${ }^{72}$ Great A. \& P. Tea Co. v. Mayor and Commissioners of Danville, 367 Ill. 310 , in N. E. (2d) $3^{88}$ (1937); Berger v. Quinn, supra note 5.

${ }_{73} \mathrm{Ky}$. StAT. (Baldwin 1938 Supp.) $\$ 2554 \mathrm{~b}-177$. $\quad{ }^{74}$ Beacon Liquors v. Martin, stupra note 60.

${ }^{75}$ Wylie v. State Board of Equalization, 21 F. Supp. 604 (I937); Silberglied v. Mulrooncy, stipra note 14; Marks v. Bruckman, I70 Misc. 709, 9 N. Y. S. (2d) 947 (1939).

${ }^{70}$ Johnson v. Liquor Control Commission, 266 Mich. 682, 254 N. W. 557 (1934); Yates v. Mulrooney, stupra note 19; Marsh and Marsh v. Carmichael, 136 Neb. 797, 287 N. W. 6r6 (1939).

${ }_{77}$ Walsh v. Bradley, II7 N. Ja L. 453, I90 Atl. 88 (1937); Fitzgerald Bros. Brewing Co. v. Meyers, Io N. Y. S. (2d) 968 (1938). However, it has been held that in the event a receiver or assignee for the benefit of creditors of an individual holding a liquor license, or in the case of the licensee's death, the state authority might permit his legal representative to continue the business for the duration of the license: Breaston v. Morgan, 257 App. Div. 34, 12 N. Y. S. (2d) 99 (r939).

${ }^{78}$ Johnson v. Liquor Control Commission, supra note 76 . 
given. But if the license confers something more valuable than a mere privilege, it will be termed a property right which may not be taken away from him without notice and hearing. Whether a license will be termed a privilege or a property right by the courts depends to a large extent upon the court's concept of the desirability of the activity licensed. ${ }^{79}$ Liquor licenses are generally termed a privilege by the courts and, therefore, in the absence of statutory provisions, the formalities of notice and hearing before revocation are not required.80 Thus in a Georgia case in which the licensing authority had revoked a license without notice or opportunity for hearing, or charge preferred against the licensee and without any violation of any law by him, the court upheld the revocation. ${ }^{81}$

Although a license is generally termed a privilege, most states provide by statute that certain formalities must be observed in revoking a license. ${ }^{82}$ Some statutes provide for a "fair hearing" before a license can be revoked. In these states, the licensee is generally entitled to formal notice of the hearing so that he will know the claims of the opposing parties. ${ }^{83}$ The notice to which the licensee is entitled is defined as follows in DeLucca's Liquor License Case:84 "Due notice means at least that the licensee be informed that he has been charged with specific violations of the liquor laws or of regulations of the Board, and will be given a hearing at a designated time and place, and such notice must be given in sufficient time to allow the licensee to prepare an answer to the charges." At the hearing, it has been held that the licensee has a right to counsel and to produce witnesses in his behalf. ${ }^{85}$ In some instances, the licensee may insist upon the right to be confronted with witnesses and cross examine them. ${ }^{86}$ In the conduct of the hearing the procedure is somewhat informal and it has been held that the strict rules of evidence which control judicial officers do not have to be rigidly enforced. ${ }^{87}$ However, a New York case ${ }^{88}$ held that "A trial which proceeds to a conclusion resulting in a quasi-judicial determination depriving a party of legal rights, can well be said to be unfair if the determination is based on a finding of fact which is not supported by Common Law proof of probative character." In another New York case, ${ }^{80}$ the requirements of a fair hearing were set out as follows, "When the statute provided for a hearing at which the licensee should be given an opportunity to be heard before his right to do business could be taken from him, and when it made the action of the liquor authority subject to review by the court, that necessarily carried with it the requirement that the

70 Gellforn, ADMinistrative Law (1940) 373.

${ }^{80}$ Blum v. Ford, supra note 25 ; State ex rel. Zugravu v. O'Brien, supra note 64 .

${ }^{81}$ McKown v. City of Atlanta, suprd note $4 \mathrm{r}$.

${ }^{82}$ City of Fairfield v. Pappas, 362 Ill. 80, 199 N. E. 292 (1935); State ex rel. Spencer v. Anderson, ror S. W. (2d) 530 (Mo. I937); Seila's Liquor License Case, 124 Pa. Super. 519, I90 Atl. 203 (1937); Bradley v. Texas Liquor Control Board, Io8 S. W. (2d) 300 (1937); Culver aNd Thomas, op. cit. supra note 3 , at 43 , Table $X$.

${ }^{83}$ Pettengell v. A. B. C. Commission, 295 Mass. 473, 4 N. E. (2d) 324 (I936); Commonwealth v. Penelope Club, supra note 63.

84 124 Pa. Super. 500, I90 Atl. I95 (1937). $\quad$ s5 State ex rel. Spencer v. Anderson, supra note 82.

${ }^{80}$ Brenner v. Bruckman, 253 App. Div. 607, 3 N. Y. S. (2d) 265 (1938).

${ }^{87}$ Yates v. Mulrooney, supra note 19.

${ }^{88}$ Townley v. Bruckman, supra note 52. $\quad{ }^{80}$ Yates v. Mulrooney, supra note Ig. 
license could be annulled on competent proof only, and made the liquor authority something more than a mere administrative body; it gives to that body quasi-judicial functions. The licensee is protected in his right to retain his license unless it be ascertained upon a hearing that good cause exists for its revocation. He must be confronted with the witness, and be given an opportunity to cross examine his accusers. Otherwise he has not had a fair hearing."

Some of the control statutes definitely specify the causes for which a license must be revoked. One of the most common of these is the violation of the liquor laws or a rule or regulation of the control authority ${ }^{00}$ In addition to the causes for which a license must be revoked, the statutes sometimes specify causes for which they may be revoked in the discretion of the authority. Other statutes merely provide that licenses must be revoked for certain causes and may be revoked for "good cause." These discretionary revocation provisions enable the licensing authority to revoke licenses which have been obtained by misrepresentation of facts by the applicant. ${ }^{01}$ A good example of this is found in a Pennsylvania case ${ }^{92}$ in which the real owner of the premises had held a license which had been revoked. Later his daughter-in-law obtained a license representing herself as the owner of the premises. The court upheld a revocation of this license on the ground that the licensee was not the bona fide proprietor of the premises. It has also been held that a license was properly revoked where the applicant misrepresented his criminal record in his application. ${ }^{93}$

It has been held that the revocation order may be made after the license expires for violations which occurred while the license was still in effect. This is well illustrated in a Pennsylvania case ${ }^{94}$ in which the court held that the license should have been revoked even though it had expired because the loss of the privilege granted by the license is not the only consequence of revocation. The licensee's bond may be forfeited, the licensee becomes ineligible to receive another license for three years and no license may be granted for the premises for a period of one year under the state statute.

Effect of revocation upon licensee's bond. It is a general practice among the license states to require applicants for licenses to provide a bond. Several cases have raised questions concerning the effect of revocation of a license upon these bonds. The courts generally construe the bonds as forfeiture bonds and not as penalty or indemnity bonds to cover any penalties which the licensee might incur or damage which he might do. ${ }^{95}$ Under this construction the entire amount of the bond may be forfeited upon revocation of the principal's license even though no fines or penalties are assessed against the licensee. The forfeiture of the bond, however, is generally

${ }^{\circ 0}$ Blum v. Ford, suprd note 25; City of Fairfield v. Pappas, supra note 82.

${ }^{91}$ In re Revocation of Marchesani's Liquor License, I22 Pa. Super. 521, I86 Atl. 266 (1936).

${ }^{02}$ Appeal of Samson, 124 Pa. Super. 110, I 88 Atl. 82 (1936).

${ }^{93}$ Appeal of Wolf, II5 Pa. Super. 514, I76 Atl. 260 (1935).

'Seila's Liquor License Case, supra note 82.

${ }^{95}$ Commonwealth v. Eclipse Literary and Social Club, Ir7 Pa. Super. 339, I78 Atl. 34I (1935); Thomas v. Kind, 222 Wis. 645,269 N. W. 543 (1936). 
held not to occur automatically upon revocation of the license.96 The tribunal revoking the license generally has a discretionary power to declare the bond forfeited. And it has been held that the omission of a prayer for forfeiture does not prevent the exercise of the power to forfeit the bond when it appears from the evidence that a proper ground exists. ${ }^{97}$

Although it is generally held that the surety has no right to notice of the revocation proceedings or to be made a party thereto, ${ }^{98}$ an unappealed from order of revocation entered against a licensee is conclusive against his surety. After the principal's license has been revoked, the surety cannot collaterally attack the revocation order in an action against the licensee to recover the amount which he had paid on the forfeiture of the bond. ${ }^{98}$ This, of course, presupposes a valid order of revocation. Thus, in the De Lucca case, ${ }^{100}$ the court reversed the decree of forfeiture of the surety's bond on the ground that the licensee had not been given proper notice of the revocation proceedings as required by statute and, therefore, the revocation order was void. As a result, there was nothing to which the decree of forfeiture could attach.

An interesting contention was made by the surety in a Missouri case ${ }^{101}$ in which the principal's license had been revoked for violation of the liquor laws of the state and the full amount of the bond forfeited. The surety contended that if the bond was a forfeiture bond, as it was construed by the court, the forfeiture of the bond violated the section of the state constitution prohibiting excessive fines and cruel and unusual punishments. The court dismissed the contention on the ground that the liability on the bond is not contingent on a criminal conviction of the licensee.

Inspection of premises without warrant as a condition of license. In order to properly regulate the liquor traffic it is essential that the control authorities have ample power to inspect premises where liquor is sold. Although the federal and state constitutions contain provisions prohibiting unreasonable searches and seizures, it is generally held that this protection may be surrendered by individuals. ${ }^{102}$ Thus, a person may consent to having his premises searched without a search warrant and the constitutional provision will not be violated by such search. Because of this, many of the control statutes expressly provide that, by accepting the license issued, the licensee consents to having the licensed premises searched or inspected without a warrant. For example, the Texas statute ${ }^{103}$ expressly provides that anyone accepting a license to sell liquor shall do so with express agreement and consent on the part of the licensee that the "Board or its agents shall at all times have the right and privilege

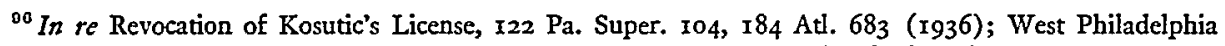
Turn- und Schulverein's Liquor License Case, I29 Pa. Super. 57, I94 Atl. 764 (1937).

${ }^{07}$ West Philadelphia Turn- und Schulverein's Liquor License Case, supra note 96.

${ }^{88}$ In re Revocation of Kosutic's License, supra note 96; De Lucca's Liquor License Case, supra note 84.

${ }^{00}$ U. S. Guaranty Co. v. Nobogis, 169 Misc. 31,6 N. Y. S. (2d) $46 \mathrm{r}$ (1938); Commonwealth v. Eclipse Literary and Social Club, stupra note $95 . \quad{ }^{100}$ Supra note 84 .

${ }_{101}$ State v. Wipke, 133 S. W. (2d) 354 (Mo. I939).

${ }^{102}$ Manchester Press Club v. State Liquor Commission, supra note 34 ; Plainos v. State, roo S. W. (2d) 367. (Tex, 1937).

103 Tex. Ann. Penat Code (Vernon r936) Art. 667.
} 
of freely entering upon the licensed premises for the purpose of supervising and inspecting said premises, and for the purpose of performing any duties imposed upon them by the Act." The act further provides that no warrant is necessary for the arrest of any persons or for the seizure of liquor unlawfully in the possession of any licensee. Finally, the act makes it a criminal offense to refuse to allow on demand the control board or any representative of the board to make a full inspection of any such place. This provision was held to be constitutional when the court in the case of Plainos v. State ${ }^{104}$ upheld the conviction of a licensee for its violation. Although other states do not have such express statutory provisions, the same result is achieved by inserting in every application for a license a statement to be signed by the applicant to the effect that permission is given the control authorities to inspect the premises at any time without a warrant. ${ }^{105}$

In a New Hampshire case, ${ }^{106}$ a licensee sued to enjoin the enforcement of a provision of the state act similar to the Texas provision on the ground that it was unconstitutional. The court upheld the statute with these comments, "The contention that the regulation is invalid on the ground that it violates the protection of the federal and state constitutions from unreasonable search, confuses beween rights and privileges. No one may sell intoxicating liquor against the state's consent, and if consent is granted, it may be on such terms and conditions as the state attaches thereto. Acceptance of the license is an acceptance of the requirements to be observed by the licensee. The requirements impose the obligation to observe them, since the obligation is one voluntarily assumed in return for the privilege. The uncompelled surrender of a right is not an invasion of the right by the recipient of the surrender, and the right to be secure against unreasonable search and seizure is one that may be yielded. No rule of public policy forbids its waiver."

This privilege of inspection by the control agency under these statutes is not unlimited, however. The court in a Maryland case ${ }^{\mathbf{1 0 7}}$ reversed the conviction of a licensee of the crime of maintaining and operating an establishment for gambling where the conviction was based upon evidence taken from the licensee's apartment, although the apartment was in the same building as the liquor store.

Other questions concerning issuance of licenses. An interesting question has been raised in a few cases concerning the effect of the statutes permitting sale of intoxicating liquors on covenants in leases forbidding such sale on the leased permises. For example, the Pennsylvania statute provided that upon compliance by an applicant with certain conditions, the Board "shall grant and issue a liquor license." Although his lease contained a covenant prohibiting sale of liquor, an applicant for a license contended that this section of the statute rendered such covenant null and void. The Board refused to grant the license on the ground of the covenant and the court on appeal ${ }^{108}$ held that the statute did not nullify the covenant or make it illegal and no

\footnotetext{
${ }^{104}$ Supra note 102. $\quad{ }^{105}$ Miller v. State, 174 Md. 362, 198 Atl. 710 (1938).

${ }^{108}$ Manchester Press Club v. State Liquor Commission, supra note 34 .

${ }^{107}$ Miller v. State, supra note 105.

${ }^{108}$ Appeal of Cheris, 127 Pa. Super. 355, 193 Atl. 162 (1937).
} 
license could be issued for such premises unless the restriction had been relinquished by deed. "The mandatory word 'shall' is necessarily limited to an applicant whose deed does not prohibit the sale of liquor."

Where the Federal Government owns land within a state, there are quite frequently problems arising as to the right of the state to require a license of a person who sells intoxicating liquors on such land. The respective rights or jurisdiction of the two governments in such situations depend upon the rights ceded to the Federal Government and the rights reserved by the state in the provisions of the cession statute. In a New Mexico case ${ }^{\mathbf{1 0 9}}$ the defendant operated a liquor store on land, situated in the state of New Mexico, acquired by the United States government, either by purchase or condemnation for reclamation purposes, to which acquisition the state had given its consent. The defendant had a federal license but no license from the state. The state of New Mexico convicted him for possessing alcoholic beverages for purposes of sale without first obtaining a license. The defendant contended that this was not necessary since the property was under the exclusive jurisdiction of the Federal Government. On appeal to the New Mexico Supreme Court, the conviction was affirmed, the court stating, "We hold it to be a principle of law that the State's jurisdiction to tax and regulate the liquor industry within its boundaries will not be presumed to have been legislated away unless such concession can be clearly found in the express statute of concession. This we do not find, . . . the United States government did not accept, nor did the state cede, exclusive jurisdiction over the land acquired for all purposes. It is sufficient to say that the Acts of Cession do not indicate any such exclusive concession as claimed by appellant. The State of New Mexico never ceded its right to regulate or tax the liquor traffic within the state of New Mexico upon lands acquired by the United States government."

But the opposite result was reached by the United States Supreme Court in the case of Collins v. Yosemite Park and Curry Co. ${ }^{110}$ In this case, the Supreme Court held that the control statutes of California had no application within the limits of the Yosemite National Park, and, therefore, the state could not require a license to sell liquor therein. "The jurisdiction over the Yosemite National Park is exclusively in the United States except as reserved to California, e.g. right to tax. . . . As there is no reservation of the right to control the sale or use of alcoholic beverages, such regulatory provisions as are found in the act under consideration are unenforceable in the Park."

\section{Administrattve and Judicial Review of Control Authority Action}

Administrative review. As was stated before, most of the license system states vest in local authorities power to participate in liquor control. In these states, an appeal from adverse action of the local authorities to the state authority is generally provided by the control statute. In some of these statutes it is further provided that

${ }^{100}$ State v. Mimms, 43 N. M. 318, 92 P. (2d) 993 (1939).

${ }^{110} 304$ U. S. 518, 58 S. Ct. roog; $f$. Crater Lake National Park Co. v. Oregon Liquor Control Commission, 26 F. Supp. 363 ( 1939 ). 
if the local authority refuses to carry out the order of the state authority's decision on appeal within a given time, such order shall be deemed to be self-executed and shall have the same force and effect as though actually complied with. ${ }^{111}$

Some of the state authorities exercise broad powers when reviewing action of a local control agency on appeal. It has been held that in reviewing the action of the local authority the state agency may take new evidence and make wide investigation into facts. ${ }^{112}$ Thus, the state authority is not limited merely to an examination of the record of the local licensing authority. The powers of the state agency on appeal are well illustrated in the opinion of the court in a Rhode Island case. ${ }^{113}$ In this case the local authority had granted a license against which a protest was made by an adjoining land owner who applied to the State Commission for review. The chairman of the State Commission was an interested party, being an owner of property adjacent to the licensed premises. On the appeal, the State Commission ordered the local authority to enter on its records a denial of the application, the chairman's vote being necessary for a majority action by the Commission. On a review of the action by writ of certiorari, the court held that the chairman was disqualified to act in this case. In the opinion, the court stated that the act confers broad powers upon the State Commission. "Each member of the Commission is authorized to administer oaths, and the Commission, by subpoena, may summon witnesses and compel them to attend and testify in like manner as either the Supreme or Superior Court. It has power to compel the production of documents, records, etc., which may be necessary by issuing a subpoena duces tecum, and also the power to punish for contempt of its processes.... In view of the wide powers given the Commission and the nature of the duties imposed upon it by the statute, it is clear that in the exercise of some of these powers it acts as a quasi-judicial body. When sitting as a board of review, it is unquestionably acting in that capacity and, as such, is bound by the same fundamental principles that are binding upon all judicial bodies. Chief among these is that all members thereof shall be free from all personal interest in the matter under consideration."

Judicial review. The question of the right of judicial review of orders and decisions of the liquor administrators has been a perplexing one. The divergent attitudes toward judicial review of decisions of the control authorities are the result of conflicting policy factors. Thus, the statement is made by those who insist on such review that "our tradition of individual freedom presupposes the right of impartial adjudication in controversial matters."114 It is felt that such matters as granting, denying or revoking licenses and promulgating rules and regulations should not be placed in the hands of administrative tribunals without some supervisory power in the courts. The countervailing policy is the need to deal conclusively with these

\footnotetext{
111 Town of Webster v. A. B. C. Commission, 295 Mass. 572, 4 N. E. (2d) 302 (1936); Conover v. Burnett, II 8 N. J. L. 438, r93 Atl. 685 (I937).

112 Boginski v. Alcoholic Beverage Commission, 4 Atl. (2d) 265 (R. I. 1939).

${ }^{113}$ Clark v. A. B. C. Commission, 54 R. I. 26, I70 Atl. 79 (I934).

${ }^{114}$ HARRISON AND LANE, Op. cit. supra note 9, at 90.
} 
matters in the first instance. In support of this view, it is said that the liquor authority's familiarity with necessary facts renders it the best judge. Also, appeals to courts provide many opportunities for the sale of liquor by undesirable persons during the period pending court action.

Most of the states provide for an appeal either to specified courts or to courts of general jurisdiction. ${ }^{115}$ However, some of the statutes have omitted any mention of a right of review. ${ }^{116}$ Other statutes have definitely denied the right of appeal by expressly providing that there shall be "no appeal" from the action of the control authorities or that such action "shall be final."117 At least one statute has provided that the decision of the control authority on questions of fact shall be final. ${ }^{118}$ In some states in which both local and state authorities have licensing power, the statutes provide for appeal from a decision of the local board to the state authority. But here again the action of the state authority may be appealed from in some states and not in others. ${ }^{119}$ In general, the necessity for exhausting administrative remedies before turning to the courts for relief is recognized in this field as elsewhere. ${ }^{119^{a}}$

It has been held in an Ohio case $\mathrm{C}^{120}$ that a statute providing that the action of the state authority in revoking a license shall be final is not a violation of the due process clause of the Federal Constitution. In this case, the local authority revoked a license. The licensee appealed, under the statute, to the state board which reviewed the revocation and upheld the action of the local authority. The licensee then brought a writ of mandamus proceeding to compel the Board to rescind the order of revocation and to reinstate the license on the ground that the provision that the decision of the state board should be final violated the Fourteenth Amendment of the United States Constitution. The court denied the writ and declared the provision to be constitutional. The pertinent language of the court was, "Where the authority to hear and determine controversies which do not involve the exercise of judicial power is conferred by the legislature upon the executive or administrative branch of state government, with finality of determination, there is no denial of due process of law under the State or Federal Constitution; so if the power to be exercised is purely executive or administrative, no recourse to the courts by appeal or error need be provided to assure the constitutional validity of the empowering act. . . . Neither the granting nor the revoking of a license by a state board under authority conferred by the legislature is an exercise of judicial power."

If the right of judicial review is provided for by statute, the control authorities cannot make their action final by refusing to receive any application for licenses. In holding that the authority must receive applications and pass upon them, the court in a New York case ${ }^{121}$ said, "The fact that the city Board may regard the per-

${ }^{110}$ Culver and Thomas, op. cit. supra note 3 , at 42 and Table $\mathrm{X}$.

${ }^{110}$ Ibid.

${ }^{117}$ Appeal of McGettigan, I3I Pa. Super. 280, 200 Atl. 213 (1938).

${ }_{118}$ Marsh v. Alcoholic Beverage Commission, 54 R. I. 57, I69 Atl. 747 (1933).

${ }^{110}$ Culver and Thomas, op. cit. supra note 3 , Table $\mathrm{X}$.

${ }_{110 \mathrm{a}}$ See note 140 infra.

${ }^{120}$ State ex rel. Zugravu v. O'Brien, supra note 64 .

${ }^{122}$ Wilson v. Quinn, 253 App. Div. 403, 2 N. Y. S. (2d) 6 (1938). 
formance of its duty as futile is no legal excuse. Such omission in effect operated as a denial of the right of judicial review of a determination of the Liquor Authority upon petitioner's application for a license."

(A) On appeal. The scope of the review of the courts on an appeal from the licensing authority is generally limited. In general the courts seek only to determine whether or not the licensing authority had jurisdiction to act and if that action was arbitrary or capricious. ${ }^{122}$ The reason for this is set out in the case of Van DeVegt $v$. Board of Commissioners. ${ }^{123}$ "Since the local authority is peculiarly fitted to determine whether, under all surrounding circumstances, the license should be granted, the court will not hold their action arbitrary where such action is based on evidence from which reasonable men might draw different conclusions." The Connecticut control statute provided that if the Superior Court on appeal finds that both place and person are suitable it shall order a license issued. However, in a case involving this provision, ${ }^{124}$ the Supreme Court of Errors said, "The court holds that the farthest the Superior Court can go is to review the action of the Commissioners to determine whether or not they had acted legally and in the exercise of reasonable discretion. Hence the act of the Commissioners must be sustained unless it appear that it acted arbitrarily."

The Texas statute provides that "An appeal from any order of the Board or Administrator cancelling or suspending a license may be taken to the District Court of the County in which the aggrieved licensee may reside. The proceeding on appeal shall be against the Board alone as defendant and the trial shall be de novo under the same rules as ordinary civil suits" except that "neither party shall be entitled to a jury." ${ }^{25}$ The latter provision dispensing with a jury has been upheld as not violating the state constitution. ${ }^{126}$ Although this statute provides for a trial de novo on appeal, the scope of the court's inquiry has been construed as follows, ${ }^{127}$ " $\mathrm{On}$ appeal from the Board's order, the District Court cannot hear testimony not produced before the Board. The Board's decision that the license should be revoked is binding upon the District Court if supported by substantial testimony and if not determined to be arbitrary or capricious." Another interesting feature of this statute is that it makes all notices, orders, rules, etc. of the Board prima facie valid, which necessarily places the burden of proof upon the one complaining. ${ }^{128}$

(B) Mandamus. Aside from statutory provisions for appeal, other devices are used in an attempt to obtain a review of the action of the control authority. The most common of these is a writ of mandamus proceeding, generally to compel the

\footnotetext{
${ }^{122}$ Gwiazda v. Borgin, supra note I4; Skarzynski v. Liquor Control Commission, 122 Conn. 521, I9r Atl. 98 (r937); In re Kulack, 254 App. Div. 826, 5 N. Y. S. (2d) 220 (1938).

${ }^{123}$ Supra note 16.

12، Skarzynski v. Liquor Control Commission, supra note I22.

${ }^{125}$ Tex. Ann. Penal Code (Vernon 1936) Art. 666-14.

120 Texas Liquor Control Board v. Jones, IIz S. W. (2d) 227 (1937).

${ }^{127}$ Texas Liquor Control Board v. Floyd, II7 S. W. (2d) 530 (1938).

${ }^{128}$ Texas Liquor Control Board v. Marine Exchange Club, supra note zo.
} 
authority to issue a license. ${ }^{\mathbf{1 2 9}}$ Since the right to a license to sell liquor is held to be a privilege, the mandamus proceeding is generally unsuccessful. ${ }^{130}$ The language used by the courts is usually to the effect that one is not entitled to a writ of mandamus unless it appears that he has a clear legal right to have performed the particular act. ${ }^{131}$ And, although a business is legalized, it does not follow that there is an absolute right to conduct such business where it is of a harmful type. ${ }^{132}$ The office of this writ is aptly stated by the court in the case of Reichelderfer $v$. Johnson. ${ }^{133}$ "Mandamus will not issue where its effect will be to dictate to an officer in the exercise of a discretionary function, or to serve the purpose of writ of error. Only where a mandatory ministerial duty is plainly imposed upon the officer will mandamus lie against him and, since the earliest cases, it has been held that where an officer's action involves the exercise of his discretion in the construction and interpretation of a statute, mandamus will not issue to compel him to act upon one construction rather than another. Mandamus will not lie if the construction of the officer is a possible one, and there is room for an honest difference of opinion."

In accordance with these principles, a writ of mandamus has been granted in two types of situations arising under the licensing systems. The first is where the control authority refuses to exercise the powers vested in it. ${ }^{134}$ For example, the Georgia control statute placed upon the governing authority of the county the duty to regulate the sale of liquor where the local option vote was affirmative. After such affirmative vote in one case the commissioners passed a resolution to grant no licenses for the county. A writ of mandamus was granted by the court to compel the commissioners to perform their duty under the act and fix the conditions under which licenses would be granted. ${ }^{135}$ Said the court, "The act authorizes discretion in the regulation of the sale, not the use of discretion in determining whether or not liquor shall be sold in the county. Where an officer is vested with discretion, the courts will not by mandamus direct in what manner he shall exercise that discretion, but they may compel the officer to exercise his discretion."

The other situation in which mandamus will lie is where the licensing authority has acted contrary to the provisions of the control statute. Thus, where the license is granted within 300 feet of a church when the statute forbade the sale of liquor within that distance from a church, school or hospital, the church was granted a writ of mandamus to compel the revocation of the license. ${ }^{136}$ Likewise, where the number (1939).

${ }^{120}$ Heuston v. Gilman, 98 Colo. 30 r, 56 P. (2d) 40 (1936); Levi v. State, 136 Fla. 806 , x87 So. 600

${ }_{130}$ Ellison v. Doyal, 182 Ga. 803, 187 S. E. II (1936); State v. Arundell, 200 Minn. 305,273 N. W. 817 (1937); Silberglied v. Mulrooney, supra note 14.

131 Hodges v. Kennedy, supra note 43; Phillips v. Head, supra note I7.

132 Thielen v. Kostelecky, supra note 43; Heuston v. Gilman, supra note 129.

${ }^{133} 63$ App. D. C. 334,72 F. (2d) 552 (1934).

${ }^{134}$ Fulton Restaurant, Inc. v. Quinn, 300 N. Y. Supp. 779 (x937); Reckler v. Quinn, 254 App. Div. 710, 4 N. Y. S. (2d) 374 (1938).

${ }^{130}$ Board of Trustees of Leland Stanford Univ. v. State Board of Equalization, 37 P. (2d) 84 (Calif. 1934); State v. Fuller, I33 Fla. 554, x82 So. 888 (1938). 
of licenses which the authority is permitted to issue is definitely fixed, mandamus will lie to compel the revocation of those licenses issued in excess of the fixed number. ${ }^{137}$

(C) Certiorari. Instead of providing for an appeal from the action of the control authority, some statutes provide that the action may be reviewed by writ of certiorari. ${ }^{138}$ However, the most frequent use of the writ of certiorari has been under those statutes which provide that the action of the licensing authority shall be final. The courts have taken three attitudes toward the availability of this writ where no provision for appeal to a court has been made. Some courts hold that a statute making the action of the control authority final does not affect the right of the court to issue a writ of certiorari in order to determine, from an inspection of the record, whether or not the authority exceeded its jurisdiction and for the purpose of correcting errors apparent on the face of the record..$^{130}$ Other courts hold that if the control statute provides for an appeal from the local to the state authority, whose decision is final, certiorari is not available to review the action of the local board. ${ }^{140}$ This is merely an application, of course, of the general principle that administrative remedies must be exhausted before seeking judicial review. In a New Jersey case, ${ }^{141}$ the court explains this position thus, "The doctrine of the general availability of the court's prerogative writ when no other remedy exists, has no application in cases when the Legislature has provided a specific remedy and a special agency for its prompt administration. It is a sound exercise of discretion, to say the least, for the courts to forward rather than to thwart such legislative policy, and this can be done only by denying allocatur where the statutory review has not been had, reserving the use of the prerogative writ for review of such statutory tribunals, rather than permitting its use to their disparagement. The discretionary nature of the writ permits, if it does not require, us to give controlling effect to these considerations."

The third attitude of the courts is that action of the licensing authority in denying or revoking a license is not reviewable by certiorari. This was the attitude of the court in a Georgia case ${ }^{142}$ in which there was a petition for a writ of certiorari after the Commission had revoked a license. The court stated that, since the selling of alcoholic beverages is a mere privilege, "the revocation of a permit granting such a privilege either with or without a hearing, or for cause or without cause, is therefore not a judicial act and is not reviewable by certiorari."

(D) Injunction, Prohibition and Habeas Corpus. Writs of injunction have been used quite frequently to test the authority of the control agency to revoke licenses and promulgate regulations. ${ }^{143}$ These actions are usually brought on the theory that

\footnotetext{
${ }^{137}$ Pettengell v. A. B. C. Commission, supra note 83 .

${ }^{138}$ Marwill Liquor Store v. State Liquor Authority, 155 Misc. 489, 280 N. Y. Supp. 6ox (1935); Gelces v. State Liquor Authority, I54 Misc. 5I7, 278 N. Y. Supp. 328 (I935).

${ }^{139}$ Portuguese-American Ind. Social Club v. Costcllo, supra note 12; Walker v. Womack, 181 Okla. 34,72 P. (2d) 510 ( 2937 ).

1\$0 Matthews v. City of Asbury Park, I13 N. J. L. 205, I74 Atl. 213 (1934).

141 Ibid.

${ }^{142}$ Acree v. Ragsdale, 60 Ga. 675, 4 S. E. (2d) 708 (1939); cf. Marsh v. Alcoholic Beverage Commission, supra note 118 .

${ }^{1 * 3}$ Marsh and Marsh v. Carmichael, supra note 76; Fylken v. City of Minot, stupra notc 7; Coady v Leonard, stipra note 5 .
} 
the statute under which the authority is acting is unconstitutional. In an attempt to obtain a review of the action of the licensing agency in revoking a license, an action is frequently brought to enjoin the agency from interfering with the plaintiff's business after the order of revocation has been rendered. ${ }^{144}$ Quite similar to the writ of injunction is the writ of prohibition which is sometimes used to determine if the control agency acted in excess of its authority. ${ }^{145}$ This writ is generally used to contest regulations made by the control authority, the contention being that the regulations were not within the scope of power vested in the control agency by the statute. Finally, where violation of provisions of the statute or of regulations of the board is made a criminal offense, the writ of habeas corpus has been used by one convicted of such violation to test the validity of the statute or regulation. ${ }^{\mathbf{1 4 6}}$

Is the statutory method of review exclusive? Since most states provide by statute for a review of the control authority's action, the question has arisen as to whether that method of review is exclusive of all others. Very few cases involving this question seem to have arisen in this field. ${ }^{\mathbf{1 4 7}}$ However, it has been held that the procedure for review provided by the control statute is the exclusive remedy. Thus, the Kentucky act provided for an appeal from the orders of the control board to a specified court. On the ground that the statutory appeal was the exclusive method of review, the Court of Appeals dismissed an action for a mandatory injunction brought by one who had not appealed from the action of the board. ${ }^{148}$

Closely related to the question of whether the statutory method of review is exclusive is the question of how results of local option elections may be reviewed. In a Texas case, ${ }^{149}$ the plaintiff contested the validity of such an election by a mandamus action against the State Liquor Board to compel issuance of a license for premises located within the local option unit. The court refused to grant the writ holding that the proper method to attack the election was by an election contest as authorized by statute, which was exclusive, and the method used in this case was a collateral attack upon the election which could not be maintained. However, in New York an attack upon a local option election by suit to enjoin the sale of liquor by one who had been granted a license after the election was successful. ${ }^{150}$ In this case the court said that the State Liquor Authority had no judicial power and, therefore, had no jurisdiction to determine the validity of a local option election. "By granting the license, the Authority in effect made a judicial determination of the validity of the election."

\footnotetext{
144 Blum v. Ford, stipra note 25; McKown v. City of Atlanta, supra note 4r.

${ }^{145}$ Alexander v. Graves, 178 Miss. 583,173 So. 4I7 (1937); State ex rel. Stewart v. Dist. Court, I03 Mont. ${ }_{487} 8,63$ P. (2d) I4I (1936); Sesselberg v. Schoenbeck, supra note 32.

${ }^{110}$ State ex rel Floyd v. Noel, supra note 52.

${ }^{217}$ Martin v. Board of Council, $275 \mathrm{Ky}$. 142, 120 S. W. (2d) 76 (I938); Marwill Liquor Store v. State Liquor Authority, supra note 138 .

${ }^{148}$ Martin v. Board of Council, stpra note 147.

${ }^{110}$ Talley v. Benson, $96 \mathrm{~S}$. W. (2d) 94 (1936). An attempt to attack another local option election in the same state by injunction proceedings met the same fate: Akers v. Remington, II5 S. W. (2d) 7I-4 (1938).

${ }_{160}$ Wall v. Great A. \& P. Tea Co., I62 Misc. 635, 295 N. Y. Supp. 360 (1937).
} 
Stay of order pending review. Where judicial review of the action of the licensing authority is provided for, the question of whether the original order of the authority should go into effect upon its issuance or be stayed pending review raises difficult problems which few of the liquor statutes have attempted to solve. If the court grants a stay of the order, an undesirable person may continue to do business for months after the order was issued. On the other hand, if the court should reverse the liquor authority's decision and the authority's order has been in effect for possibly months, the trade of the licensee may have been ruined. Some of the states, however, have attempted to meet this dilemma by providing that the court of appeal may grant a stay of the order not exceeding a certain period of time. ${ }^{151}$ Thus, the New York Act provides that no stay shall be granted except on notice to the liquor authority and for a period not exceeding thirty days. ${ }^{152}$ In the case of Yacht Club Catering v. Bruckman, ${ }^{153}$ the court refused to grant a further stay of the order making these comments on the statute: "To insure that the Liquor Authority acts lawfully and to protect the rights of individuals, the determination of the Liquor Authority is subject to review by the court. Irreparable damage to the individual might result if, pending the determination of the court upon such review, an erroneous or arbitrary order of the Liquor Authority were enforced. On the other hand, respect for the law is weakened to the public detriment whenever the state is delayed, even by legal process, in stopping any act which is in fact unlawful and which has been declared unlawful by the public authority vested with power to determine its legality . . . the Legislature has decided to impose that limitation, and the courts may not disregard it or give to the statute a construction which would thwart the legislative intent. When it imposed that limitation it did not intend that the limitation might be evaded by successive stays."

Providing for such a limited stay protects the rights of the licensee affected and at the same time meets, to some extent at least, the argument against judicial review that an undesirable person may continue business for months pending review. However, the effectiveness of such a limited stay is very largely dependent upon the facility with which review of the action of the licensing authority may be obtained in the courts. If it is a matter of months before the appeal can be considered by the court, the stay is of little value as a protective measure for the licensee.

While the great variety in the licensing laws themselves makes extensive generalization hazardous, it seems obvious, that in the great majority of cases in this field the courts have not been inclined to interfere with legislative pronouncement or administrative activity. This makes the responsibility of the licensing agencies all the more grave, and, from the public standpoint, it becomes all the more important to insist on a quality of administrative personnel capable of exercising these comparatively unfettered powers.

\footnotetext{
${ }^{26 x}$ Culver and Thomas, op. cit. supra note 3 , at 49.

${ }^{102} \mathrm{New}$ York Alcoholic Beverage Control Law, §121.

${ }^{153} 267$ N. Y. 44 , II N. E. (2d) 345 (1937).
} 